\title{
DESAIN APLIKASI SALIM SEBAGAI MEDIA PEMBELAJARAN UNTUK MENANGGULANGI TINDAKAN KENAKALAN REMAJA
}

\author{
Masnuna ${ }^{1}$, Nungky Indah Kusuma Wardani ${ }^{2}$, Ristia Kadiasti ${ }^{3}$ \\ 1,2Desain Komunikasi Visual, Fakultas Arsitektur Dan Desain, Universitas Pembangunan Nasional \\ "Veteran" Jawa Timur, ${ }^{3}$ D4 Animasi, Fakultas Ilmu Komputer, Universitas Dian Nuswantoro \\ masnuna.dkv@upnjatim.ac.id ${ }^{1}$, nungkyindah1004@gmail.com² ${ }^{2}$, ristiakadiasti@dsn.dinus.ac.id ${ }^{3}$
}

\begin{abstract}
Abstrak
Kenakalan remaja sering terjadi karena kurangnya persiapan remaja dalam menerima perubahan yang terjadi seperti perubahan jasmani, tingkat emosi, akhlak, sosial serta cara bertindak dan berpikir. Tindakan ini sering dialami oleh remaja pada rentan usia 15 hingga 20 tahun baik laki-laki maupun perempuan. Menanggulangi masalah kenakalan remaja melalui bidang agama menjadi salah satu solusi yang dipilih sebagai pondasi utama sebagai umat beragama, sehingga dibutuhkan media melalui 2 tahapan metode yaitu tahap persiapan dan tahap penciptaan. Tahap persiapan meliputi pengumpulan data, analisis data, sintesis, dan penentuan objek perancangan. Tahap penciptaan meliputi pra produksi, produksi, dan pasca produksi. Hasil dari metode yang digunakan menghasilkan konsep "Petualang Kebaikan", yaitu orang yang bertualang mencari sifat manusia yang sesuai dengan aturan agama Islam. Media ini dirancang untuk media bantu bagi remaja dalam mengontrol perilaku sehari-hari. Apakah pada hari itu para remaja sudah berbuat baik dan bermanfaat bagi orang lain dan lingkungannya atau belum. Jika pada hari itu belum berbuat baik, maka dalam aplikasi poin-poin berbuat baik belum terceklis, begitu juga sebaliknya sehingga para remaja bisa mengontrol dirinya sendiri untuk menghindari perbuatan buruk dan melakukan perbuatan baik dalam kehidupan sehari-harinya.
\end{abstract}

Kata Kunci: android, aplikasi, multimedia, kenakalan, remaja

\begin{abstract}
Teenager delinquency often happened due to a lack of preparation for teenagers to accept changes such as physical change, emotion, attitude, social, and the way to act and think. This action often experienced by teens at a susceptible age of 15 until 20 years, whether men or women. Overcoming the problem of Teenage delinquency through the religious area becomes one of the solutions chosen as the foundation for a religious congregation, so it needs the media through 2 stages of a method that are preparation stage and production stage. The preparation stage includes data collection, data analysis, synthesis, and the definition of object design. The production stage includes pre-production, production, and post-production. The result of the methods used to generate the "Petualangan Kebaikan" concept, which is persons that travel searching for human nature that appropriate with the rule of Islam. This media designed for media support for teenagers in controlling daily attitudes. Whether on that day the teenager has done a good and beneficial deed for others and the environment. If in that the day the teenager hasn't done a good deed yet, in applications good deed points will not check or vice versa, so the teenager could control themselves to prevent horrible deed and doing a good deed in daily life..
\end{abstract}

Keywords: android, gadget, interactive, multimedia, teens 


\section{PENDAHULUAN}

Kenakalan remaja menjadi salah satu permasalahan yang cukup meresahkan bagi masyarakat umum dan orang tua. Hal ini terjadi karena remaja kurang siap dalam mengimbangi perubahan yang mereka alami seperti perubahan jasmani, tingkat emosi, akhlak, sosial serta cara bertindak dan berpikir. Jika tidak segera diatasi, remaja akan terjebak dalam kebimbangan yang dapat memicu kenakalan remaja. Tindakan tersebut paling sering dialami oleh remaja pada usia 15 hingga 19 tahun serta pada usia 20 tahun keatas. Beberapa alasan yang mendasari terjadinya kenakalan remaja yaitu faktor keluarga sebagai tempat remaja mendapatkan pendidikan pertama, pendidikan formal yang didapatkan remaja diluar lingkungan keluarga seperti sekolah, dan peranan masyarakat dalam menanggulangi kenakalan remaja (Sumara et al., 2017),

Lingkungan keluarga sebagai faktor penting dalam menanggulangi kenakalan remaja perlu memberikan pendidikan watak dan kepribadian kepada remaja. Sehingga dapat menumbuhkan rasa tanggung jawab sosial dan menanamkan moralitas dalam diri remaja. Serta meningkatkan keharmonisan dalam lingkungan keluarga untuk menciptakan suasana yang nyaman dan bersahabat. Maka remaja akan terbuka dan percaya kepada orang tua hingga terbentuk ikatan yang kuat antara orang tua dan anak. Tidak hanya itu, remaja juga perlu memperkuat keyakinan dalam beragama sebagai pedoman utama dalam menjalani kehidupan salah satunya agama Islam. (Fatmala \& Yelianti, 2016)

Islam telah mengajarkan untuk memiliki dan menerapkan akhlak baik di kehidupan sehari-hari. Memiliki akhlak yang baik juga dapat menghindarkan remaja dari perbuatan buruk yang dapat merugikan diri sendiri. Akhlak terpuji perlu diterapkan dimana saja dan kapan saja tanpa memandang siapa. Mengingat manusia merupakan makhluk sosial, dengan membangun akhlak baik di kehidupan masyarakat akan menumbuhkan keharmonisan dan kesejahteraan dalam hidup. Akan tetapi, tidak semua remaja memiliki minat yang cukup tinggi untuk mempelajari tentang ilmu agama. (Qolbiyyah, 2017)

Pemilihan media yang digunakan dalam pembelajaran ilmu agama menentukan tinggi rendahnya minat remaja untuk mempelajari tentang ilmu agama. Penggunaan buku paket atau presentasi cukup membosankan bagi remaja karena tidak ada interaksi yang menarik dan remaja hanya mendengarkan saja. Tidak hanya itu, agar ilmu agama dapat diterapkan dengan baik maka pemahaman ilmu agama juga perlu diberikan secara aplikatif kepada remaja. Maka remaja dapat memahaminya dengan baik, dalam hal ini memahami tentang akhlak baik dan buruk yang ada dikehidupan sehari-hari. Oleh karena itu perlu adanya media pembelajaran yang menarik dan interaktif sehingga remaja mampu mempelajari ilmu tentang akhlak secara teoritis dan aplikatif.

Sesuai hasil wawancara dengan narasumber bahwa pembelajaran agama di kelas saat ini membosankan bagi remaja jika tidak ada media tambahan atau cara khusus yang digunakan untuk membangkitkan semangat remaja. Sedangkan remaja perlu memahami materi akhlak tidak hanya secara teoritis melalui buku tetapi juga secara 
aplikatif di kehidupan sehari-hari. Beliau mencontohkan seperti sistem buku laporan yang sering digunakan di jenjang SD ketika di bulan Ramadan, sistem ini juga berlaku untuk remaja tingkat SMP dan SMA sehingga guru juga dapat mengawasi perilaku remaja lalu mencarikan solusi dalam penanganannya. Dari hasil wawancara ini maka media aplikasi android dipilih karena media ini sangat dekat dengan remaja. Dalam sehari para remaja bisa dipastikan akan bersentuhan dan menggunakan media ini. Sehingga, aplikasi android dirasa sangat tepat dipilih sebagai media bantu dalam mendekati remaja.

Oleh karena itu perlunya menggunakan multimedia interaktif dalam membangkitkan minat belajar remaja tentang ilmu agama dengan memperhatikan dari segi desain dan interaktif. Penggunaan tampilan desain yang menarik serta konsep interaktif yang dapat digunakan dalam kegiatan sehari-hari menjadi aspek yang perlu diperhatikan (Munir, 2012). Mengingat kurangnya aplikasi Islami yang membahas tentang akhlak sehari-hari. Sehingga perlu adanya pembaruan dalam konsep desain yang digunakan demi menarik minat pengguna dan kemudahan dalam berinteraksi terhadap multimedia interaktif.

\section{METODE PENELITIAN}

Penelitian ini menggunakan dua tahapan metode yaitu tahap persiapan dan tahap penciptaan. Tahap persiapan meliputi pengumpulan data, analisis data, sintesis, dan penentuan objek perancangan. Kemudian tahap penciptaan meliputi pra produksi, produksi, dan pasca produksi. (Sugiyono, 2018)

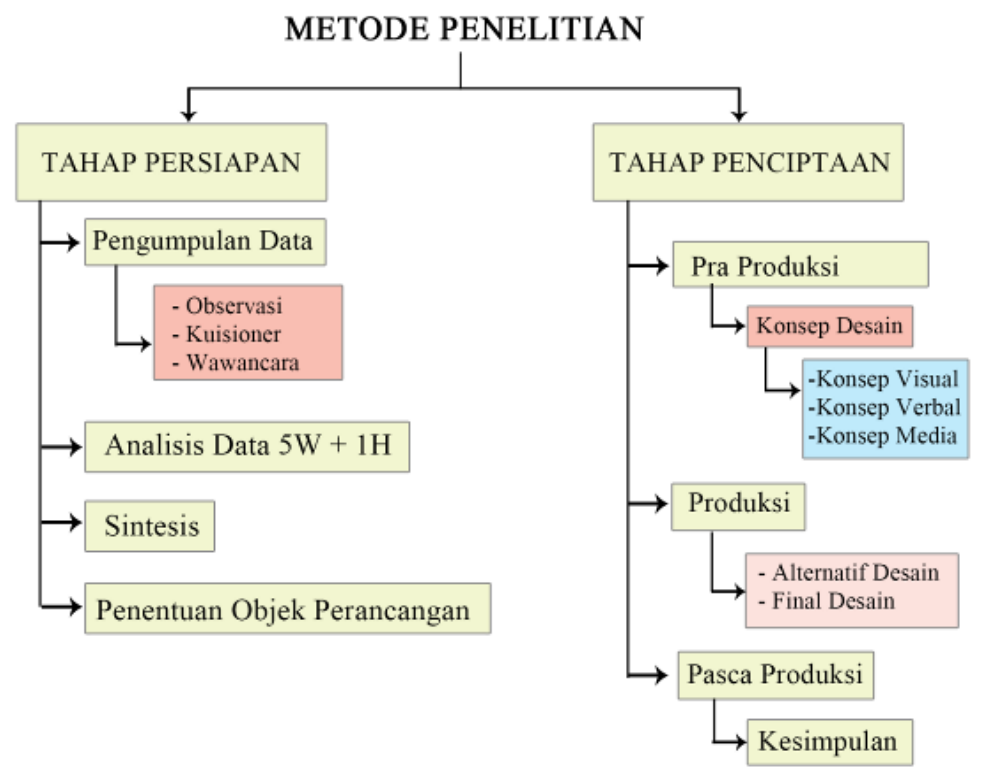

Gambar 1. Metode penelitian

[Sumber : Dokumentasi Peneliti]

\subsection{Tahap Persiapan}

\subsubsection{Pengumpulan Data}

Data dikumpulkan menggunakan metode kualitatif agar mendapatkan data yang akurat dan mendalam. Tahapan yang digunakan dalam pengumpulan data yaitu 1) Observasi; Observasi merupakan teknik pengumpulan data yang mengandalkan pengamatan untuk 
mengamati fenomena yang ada di ligkungan sekitar sehingga membutuhkan ketelitian dan ketajaman mata dalam melihat fenomena hingga skala terkecil. Observasi dilakukan sebagai teknik untuk mengumpulkan data primer yaitu data yang didapatkan langsung dari target audiens. Proses ini dilakukan dengan mengamati secara langsung bagaimana kebiasaan remaja di waktu luang atau saat berkumpul dengan teman (Abdullah, 2015). Fenomena yang diamati berupa hal-hal yang berkaitan dengan target audiens seperti fenomena yang terjadi di kalangan remaja, menentukan target audiens sebagai sample, mencari kebiasaan remaja dalam waktu satu hari, penggunaan gawai bagi remaja, perilaku remaja, respon remaja hingga saat menghadapi kondisi tertentu. Selain itu, hal yang perlu diamati adalah karakter atau respon remaja dalam menyikapi suatu hal kecil baik yang memberikan keuntungan atau keburukan untuk mereka. Hasil dari observasi bisa digunakan untuk menarik kesimpulan belum ada atau tidaknya penerapan akhlak dalam kehidupan sehari-hari.

2) Kuesioner; Kuesioner merupakan teknik pengumpulan data yang menggunakan beberapa pertanyaan dan pernyataan secara tertulis yang disebar kepada responden. Teknik ini digunakan untuk mencari pendapat atau jawaban pribadi secara langsung dari target audiens. Pertanyaan tersebut seperti pendapat mereka tentang suasana pembelajaran di kelas, penggunaan media pembelajaran di kelas hingga tokoh masyarakat yang mereka idolakan yang akan dijadikan sebagai acuan karakter dalam multimedia interaktif.

3) Wawancara Mendalam; Wawancara mendalam dilakukan untuk mendukung hasil dari observasi dan kuesioner berdasarkan pendapat dari narasumber yang berkaitan. Serta menggali informasi dari target audiens tentang keinginan terdalam mereka yang berkaitan dengan perancangan. Hasil data ini akan dijadikan sebagai salah satu pertimbangan dalam penyusunan konsep. Adapun narasumbernya adalah (a) Narasumber pertama yaitu bapak Dzulfikar Akbar Romadhon, M.Ud selaku dosen fakultas agama Islam di Universitas Muhammadiyah Sidoarjo. Data yang dicari berupa peran akhlak dalam kehidupan sehari - hari terutama dalam menyikapi fenomena kenakalan remaja saat ini, akhlak apa saja yang seharusnya diterapkan serta pendapat pribadi beliau tentang penelitian ini. (b) Narasumber kedua yaitu beberapa ilustrator untuk mencari data tentang desain yang berkaitan dengan penelitian. (c) Narasumber ketiga yaitu beberapa remaja antara usia 16 - 18 tahun di Surabaya. Data yang dicari berupa keseharian remaja saat hari biasa dan hari libur serta cara mereka menggunakan gawai.

\subsubsection{Analisis Data}

Setelah mengumpulkan data, langkah selanjutnya menganalisis data menggunakan metode $5 \mathrm{~W}+1 \mathrm{H}$. Data dianalisa dimulai dari perumusan masalah atau fenomena yang ada, hingga terkumpulnya data yang dibutuhkan lalu ditarik satu kesimpulan. Penelitian ini berfokus pada teknik analisa $5 \mathrm{~W}+1 \mathrm{H}$ untuk mendapatkan analisis permasalahan yang lengkap sehingga menghasilkan solusi yang tepat dan efektif. 


\subsubsection{Sintesis}

Sintesis adalah kesimpulan hasil dari analisis data. Hal ini menyangkut keyword dan konsep desain. Dengan adanya sintesis maka proses pencarian keyword akan lebih mudah.

\subsubsection{Objek Perancangan}

Perancangan ini menggunakan media aplikasi yang menjadi perantara dalam mengajarkan akhlak terpuji dalam Islam. Materi akan disampaikan deskripsi to the point tentang pengertian akhlak terpuji yang juga disertai dengan contoh fenomena kenakalan remaja saat ini. Tujuan disertakan fenomena tersebut untuk memberitahukan manfaat apa yang didapat saat menerapkan akhlak terpuji tersebut. Remaja juga dapat mengetahui dampak apa yang didapat terkait dengan fenomena kenakalan remaja jika tidak menerapkannya. Dalil akan dicantumkan sebagai teori pendukung dari Al-Qur'an dan menunjukkan kebenarannya dalam Al-Qur'an.

Pemilihan materi akan disajikan dalam bentuk beberapa pilihan menu yang bisa diakses sesuai keinginan target audiens. Visual diperlukan untuk menunjukkan tindakan atau hak yang terkait dengan materi sehingga target audiens mendapat gambaran maksud dari materi secara langsung. Keberadaan visual juga menjadi salah satu aspek yang dapat menarik minat belajar dan perhatian remaja.

Target audiens dari perancangan ini meliputi; 1) Demografis yaitu Laki-laki dan perempuan dengan rentang usia 16-18 tahun, memiliki status sebagai pelajar, dan beragama Islam, 2) Psikografi yaitu audiens yang suka berkumpul dengan teman, sering bermain di cafe, warung, atau sejenisnya, sering menggunakan gawai, dan menggunakan gawai untuk hiburan, 3) Geografis yaitu remaja yang hidup di perkotaan di Indonesia.

\subsection{Tahap Penciptaan}

\subsubsection{Pra Produksi}

Pra produksi meliputi penyusunan konsep desain. Konsep desain dibuat berdasarkan keyword. Konsep desain terdiri dari konsep visual, konsep verbal, dan konsep media. Konsep visual meliputi ilustrasi, tipografi, warna. Sedangkan konsep verbal meliputi Bahasa yang digunakan dalam buku, teknik komunikasi, cara penyampaian, kalimat yang digunakan. Sedangkan konsep media meliputi ukuran media, bahan media, pemilihan media pendukung, pemilihan media promosi, dll.

\subsubsection{Produksi}

Tahap ini adalah tahap membuat desain untuk media perancangan ini. Membuat beberapa alternative desain kemudian dipilih satu yang terbaik lalu di implementasikan ke medianya. Pemilihan final desain dipilih atasa dasar pilihan targer audiens melalui kuisioner. 


\subsubsection{Pasca Produksi}

Di tahap ini saatnya membuat kesimpulan dan evaluasi untuk mengetahui kekurangan yang harus diperbaiki dan kelebihan yang harus dipertahankan dalam perancanagan ini. Dan juga berisi harapan untuk perancangan yang akan datang.

\section{HASIL DAN PEMBAHASAN}

\subsection{Hasil Pengumpulan Data}

Setelah melakukan observasi, didapatkan data bahwa remaja memiliki kecenderungan untuk melakukan tindak kenakalan remaja lebih tinggi daripada berperilaku baik. Tindak kenakalan remaja yang dilakukan cenderung ke tindakan-tindakan kecil seperti mengejek teman, berkata kotor, berburuk sangka, membicarakan hal buruk dibelakang orang lain dan kurangnya mentaati peraturan yang menurut mereka terlalu mengekang. Tetapi ada beberapa remaja yang pernah melakukan tindakan yang cukup besar seperti balapan liar pada malam hari. Hal ini terjadi dikalangan remaja pelajar laki-laki dan perempuan.

Mereka juga memiliki kebiasaan seringnya menggunakan gawai dimana dan kapan saja meski mereka sedang berkumpul. Hampir semua remaja selalu menggunakan gawai untuk bersosial media, mencari informasi dan bermain permainan bersama temanteman mereka. Bahkan dalam kehidupan sehari-hari mereka tidak bisa lepas dari penggunaan gawai.

Setelah menyebarkan kuesioner kepada responden, didapatkan hasil sebagai berikut yaitu a) Suasana pembelajaran akhlak di Sekolah dirasa cukup menyenangkan berdasarkan hasil kuisioner yang menyebutkan bahwa 8 orang memilih sangat menyenangkan, 15 orang memilih menyenangkan, 22 orang cukup menyenangkan, dan 11 orang memilih tidak menyenangkan. b) Media Pembelajaran yang digunakan di Kelas masih menggunakan buku paket sebagai media yang sering digunakan berdasarkan hasil kuisioner yang menyebutkan 26 orang memilih Buku Paket, 12 orang memilih Powerpoint, 12 orang memilih Multimedia Interaktif, dan 1 orang memilih LKS. c) Keefektifan buku paket sebagai media pembelajaran dirasa kurang efektif melihat prosentase hasil kuisioner yang menunjukkan $82,4 \%$ menyebutkan pilihan tidak efektif dan hanya $17,6 \%$ yang menyebutkan iya. d) Pentingnya media pembelajaran yang baru tentang akhlak dirasa oleh responden sangat penting yaitu sebanyak $96,1 \%$ memilih iya dibanding 3,9\% yang memilih tidak.

Menurut hasil wawancara dengan Bapak Dzulfikar selaku dosen Pendidikan Agama Islam, menyatakan bahwa pada dasarnya pembelajaran agama di kelas memang membosankan bagi remaja jika tidak ada media tambahan atau cara khusus yang digunakan untuk membangkitkan semangat remaja. Sedangkan remaja perlu memahami materi akhlak tidak hanya secara teoritis melalui buku tetapi juga secara aplikatif di kehidupan sehari-hari. Beliau mencontohkan seperti sistem buku laporan yang sering digunakan di jenjang SD ketika di bulan Ramadan, sistem ini juga berlaku untuk remaja tingkat SMP dan SMA sehingga guru juga dapat mengawasi perilaku remaja lalu mencarikan solusi dalam penanganannya. 
Hasil dari wawancara kepada target audiens, menyatakan bahwa mereka ingin belajar dengan cara yang menyenangkan dan menarik. Tidak hanya mengandalkan media buku paket yang dinilai kurang efektif dan membosankan. Rasa bosan itulah yang mengakibatkan kurangnya minat sebagian remaja akan keinginan untuk belajar tentang agama terutama akhlak baik.

\subsection{Hasil Analisis Data}

Data selanjutnya dianalisis menggunakan $5 \mathrm{~W} 1 \mathrm{H}$ yaitu sebagai berikut:

1) What; fenomena apa yang sedang terjadi saat ini. Masalah yang terjadi dalam penelitian ini adalah tentang masalah kenakalan remaja yang meresahkan masyarakat.

2) Who; siapa target audiensnya. Target audiens adalah remaja usia 13 - 18 tahun. Berdasarkan hasil kuesioner dan artikel berita, kenakalan remaja sering terjadi pada batasan usia tersebut.

3) Where; dimana permasalahan tersebut terjadi. Demografisnya adalah di kota Surabaya dan beberapa kota di sekitarnya.

4) When; kapan masalah ini terjadi. Perancangan ini mengambil waktu di tahun 2018 karena fenomena kenakalan remaja telah terjadi sejak awal 2018.

5) Why; alasan terjadinya permasalah ini. Beberapa faktor penyebab munculnya kenakalan remaja karena kurangnya pendidikan karakter yang diberikan oleh orang tua sejak dini, pengaruh lingkungan yang buruk, arus globalisasi yang kurang terfilter dengan baik, rendahnya pendidikan agama, dan lain - lain.

6) How; bagaimana solusinya untuk menyelesaikan masalah tersebut. Mengingat kebiasaan remaja yang selalu menggunakan gawai disetiap saat, maka diambillah multimedia interaktif yang diimplementasikan dalam aplikasi Android sebagai media penyampaian akhlak. Kenakalan remaja dapat diatasi atau ditanggulangi dengan memberikan remaja pendidikan tentang budi pekerti dan perilaku baik. Mendekatkan diri kepada Sang Pencipta melalui penerapan akhlak terpuji dikehidupan sehari - hari. Serta mencegah kenakalan remaja yang terjadi di sekitar kita dengan membantu melerai pertengkaran atau membantu pihak berwajib dalam menangani kasus kenakalan remaja. Materi akhlak terpuji disampaikan melalui pembelajaran yang interaktif, yaitu pengajar memberikan gambaran dari akhlak tersebut berupa cerita di kehidupan nyata. Sehingga remaja bisa mendapatkan gambaran langsung dari maksud yang disampaikan dalam buku pelajaran. Remaja juga mampu membayangkan langsung cerita tersebut dan lebih mudah memahaminya. Akhlak terpuji dapat disampaikan kepada remaja melalui media pembelajaran yang menarik. Media pembelajaran yang digunakan harus memiliki interaksi dengan pengguna agar bisa digunakan sesuai dengan keinginan dan kebutuhan remaja. Desain yang digunakan dalam media menyesuaikan dengan selera dan karakter remaja, mulai dari visual yang cocok dengan karakter remaja yang bersemangat dan bertanggung jawab, kombinasi warna yang menarik dan menyenangkan, serta tata letak yang dibuat dengan rapi dan sederhana.

Hasil dari metode $5 \mathrm{~W} 1 \mathrm{H}$ menyebutkan bahwa kenakalan remaja sering terjadi pada usia sekitar 13 hingga 25 tahun yang didominasi pada usia sekitar 13 hingga 18 tahun yaitu 
pelajar SMP dan SMA. Tindakan kenakalan remaja dapat terjadi di sekolah, rumah dan lingkungan masyarakat bahkan bisa terjadi kapan saja. Maka media yang cocok untuk mengenalkan akhlak terpuji berupa multimedia interaktif agar remaja tidak mudah bosan saat mempelajari tentang akhlak. Agar penggunaan multimedia interaktif mudah dan bisa digunakan kapan saja maka output multimedia tersebut diubah dari CD pembelajaran menjadi aplikasi berbasis Android. Sehingga remaja dapat mengakses melalui gawai masing-masing dan mengunduhnya di Playstore. Dapat disimpulkan bahwa diperlukan media pembelajaran yang menarik dalam mempelajari akhlak terpuji agar remaja tidak mudah bosan dan jenuh. Kemudian desain menggunakan warna yang menyenangkan agar remaja lebih merasa nyaman dan bersahabat. Serta membawa konsep buku laporan tentang akhlak baik sebagai USP yang digunakan dalam aplikasi sehingga lebih interaktif.

\subsection{Sintesis}

Kesimpulan yang dapat diambil dari data-data yang dikumpulkan, bahwa pembelajaran akhlak perlu di pahami secara teoritis dan secara aplikatif agar remaja mengetahui secara spesifik tindakan apa saja terkait dengan akhlak. Saat ini media pembelajaran akhlak hanya menjelaskan secara teoritis, belum ada media yang mendukung dalam bidang agnitif siswa. Sehingga diperlukan sebuah media yang menyampaikan materi akhlak bersifat teks naratif secara singkat dan jelas yang didukung dengan animasi tentang tindakan yang berkaitan. Untuk menunjang bidang agnitif remaja, menambahkan sebuah catatan harian yang digunakan untuk mengevaluasi perilaku remaja yang membentuk sebuah dorongan untuk berusaha memperbaiki kekurangan yang dimiliki dan mempraktekkan akhlak terpuji secara konsisten.

Agar menarik minat remaja dalam menggunakan media tersebut, desain yang digunakan akan menyesuaikan dengan selera remaja atau mengikuti trend visual yang dapat dicek pada dribbble.com. Gaya gambar yang sering digunakan pada desain aplikasi berdasarkan hasil wawancara adalah flat desain. Pada dribbble.com didapatkan beberapa contoh guideline menarik dari beberapa desainer yang dapat dijadikan sebagai acuan dalam perancangan ini.
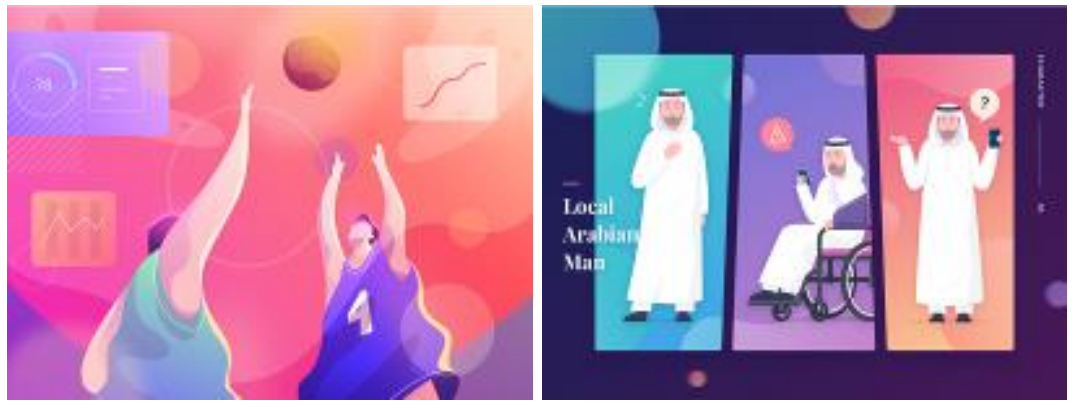

Gambar 2. Gaya flat design sebagai rujukan gaya desain [Sumber : dribbble.com] 


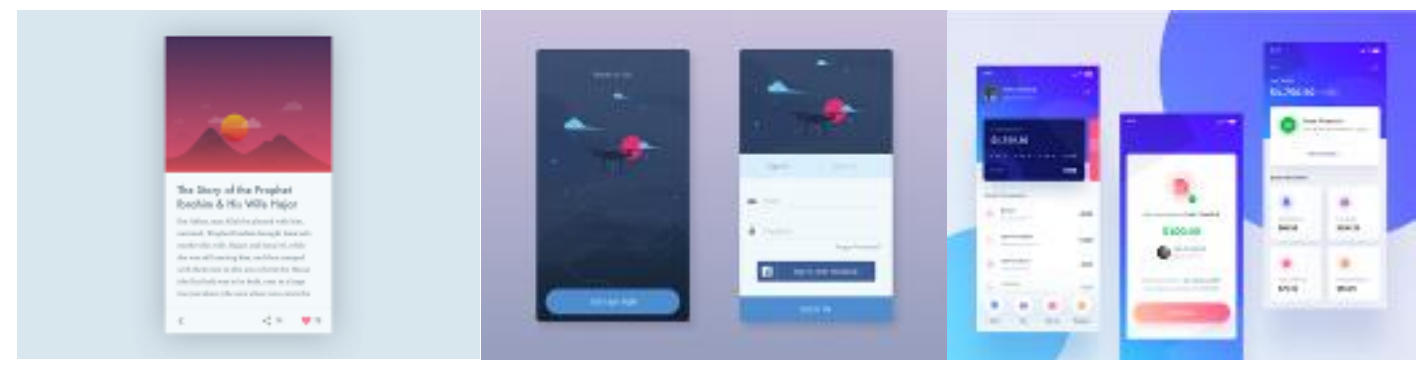

Gambar 2. Gaya desain aplikasi mobile sesuai trend visual

[Sumber : dribbble.com]

\subsection{Konsep Desain}

Setelah data primer dan sekunder dianalisa untuk menarik satu kesimpulan. Tahap berikutnya peneliti akan menemukan keyword yang digunakan sebagai acuan konkret dalam pengerjaan tahap selanjutnya. Berdasarkan data yang telah dikumpulkan, menunjukkan bahwa perlunya media pembelajaran baru yang menarik dan interaktif. Tidak hanya dapat dipahami secara teoritis tetapi juga secara aplikatif oleh remaja. Serta agar mudah digunakan dan diakses oleh remaja, multimedia interaktif ini menggunakan gadget sebagai outputnya nanti sehingga menghasilkan aplikasi pembelajaran yang berbasis Android. Tidak hanya itu, multimedia interaktif ini juga perlu didesain semenarik mungkin agar remaja tertarik dan nyaman dalam menggunakannya di kehidupan sehari-hari.

Perancangan ini menggunakan keyword "Petualang Kebaikan" menciptakan sebuah media pembelajaran yang menarik, tidak hanya menyediakan informasi tentang akhlak terpuji tetapi juga mengajak remaja untuk aktif dalam mengingat kembali dan mempelajarinya. Melalui multimedia interaktif, remaja akan diajak untuk aktif dalam mempraktikkan beberapa perbuatan baik yang disediakan. Sehingga remaja nantinya akan memiliki kebiasaan baru untuk berbuat baik yang terbentuk secara perlahan. Serta dengan penjelasan materi yang mudah dipahami dan menyenangkan, remaja tidak akan mudah bosan.

Sesuai makna denotatif, Menurut Kamus Besar Bahasa Indonesia, "Petualang" yaitu orang yang bertualang atau menyukai hal-hal yang ekstrim dan menantang untuk mendapatkan pengalaman baru, sedangkan arti kata bertualang adalah mengembara kemana - mana atau selalu melakukan perjalanan atau berpergian sehingga tidak menetap dalam rumah. Kata "Kebaikan" memiliki arti yaitu perbuatan baik, sifat manusia yang dianggap baik menurut sistem norma dan pandangan umum yang berlaku. Jika kedua makna tersebut digabungkan, maka didapatkan sebuah kesimpulan bahwa "Petualang Kebaikan" adalah orang yang bertualang mencari sifat manusia yang sesuai dengan aturan yang berlaku. Aturan yang dimaksud yaitu aturan dalam agama Islam.

Keyword ini dipilih dengan tujuan dalam menciptakan sebuah media pembelajaran yang menarik, tidak hanya menyediakan informasi tentang akhlak terpuji tetapi juga mengajak remaja untuk aktif dalam mengingat kembali dan mempelajarinya. Melalui 
multimedia interaktif, remaja akan diajak untuk aktif dalam menentukan dalam beberapa soal pilihan yang disediakan dan mencari kebaikan yang harus mereka praktikkan dalam memperbaiki kekurangan dalam sifat mereka. Serta dengan penjelasan materi yang mudah dipahami dan menyenangkan, remaja tidak akan mudah bosan. Sehingga remaja tidak hanya mempelajari tetapi juga langsung mempraktikkan apa yang telah disampakan dalam materi.

Judul dari multimedia interaktif ini adalah "Salim : Cara Asik Jadi Baik", multimedia interaktif yang membahas tentang akhlak baik. Melalui multimedia ini diharapkan remaja mampu mengimplementasikan akhlak terpuji di kehidupan sehari-hari, tidak hanya dipelajari saja. Konten yang dibahas dalam perancangan ini tentang akhlak terpuji dalam Islam pada umumnya yang perlu dipelajari oleh remaja. Materi akhlak akan dijelaskan secara singkat dan dilengkapi beberapa hadist dan ayat Al-Qur'an sebagai penunjang. Tidak hanya itu, agar remaja tidak lupa dengan materi yang telah dipelajari maka disediakan sebuah catatan yang berisikan beberapa kegiatan sehari-hari yang berkaitan dengan akhlak. Sehingga remaja dapat mengetahui hal-hal baik atau buruk apa saja yang telah dia perbuat dalam sehari dan membuat keputusan apakah akan memperbaikinya atau membiarkan seperti biasanya.

\subsection{Konsep Media}

Media menggunakan multimedia interaktif yang berisi tentang akhlak baik dalam Islam untuk mengenalkan kembali tentang akhlak dan fitur ceklis akhlak terpuji yaitu laporan dalam aplikasi yang diisi oleh remaja tentang beberapa kebiasaan baik yang telah mereka kerjakan sebagai keunikan yang dimiliki oleh aplikasi ini. Agar mudah didapatkan dan diakses oleh remaja, multimedia interaktif menggunakan output aplikasi yang berbasis OS Android sehingga remaja dapat mengunduhnya melalui Playstore. Bahkan aplikasi ini juga dapat diunduh oleh semua kalangan umur bagi yang tertarik dalam menggunakan aplikasi ini.

Berikut beberapa media sekunder dalam perancangan ini; 1) Logo; Logo dibuat dari nama multimedia interaktif yaitu "salim" yang memiliki ikon centang yang terbentuk dari huruf "a" dan "I" yang menggunakan font Anthemie lowercase. Serta menggunakan tagline yang berbunyi "Cara Asik Jadi Baik" yang menggunakan font Futura Bk BT. Makna dari logo ini adalah harapan agar remaja mampu menyempurnakan akhlaknya melalui aplikasi tersebut dengan membiasakan untuk berbuat baik secara perlahan-lahan dan konsisten. Elemen warna yang digunakan dalam logo ini adalah warna biru muda dan hijau, serta penggunaan warna gelap untuk gradasi dibagian tertentu. Warna ini dipilih untuk menunjukkan pendidikan agama Islam yang dimasukkan dalam aplikasi ini. 2) Poster; Poster digunakan untuk menyampaikan informasi tentang peluncuran aplikasi "salim" kepada masyarakat terutama remaja sebagai target audiens utama dalam perancangan ini. 3) Hoodie; Hoodie merupakan salah satu media pendukung yang dapat dibeli dengan menghubungi kontak yang tercantum pada aplikasi. Alasan pemilihan media ini karena hoodie cukup umum digunakan oleh remaja sehingga membantu penyebaran atau pengenalan nama aplikasi "salim" kepada remaja lain. 4) Kaos; Kaos merupakan salah satu media pendukung yang digunakan karena sifatnya yang umum 
digunakan oleh semua kalangan. Untuk mendapatkannya, pengguna dapat membelinya dengan menghubungi kontak yang telah disediakan pada menu Merchandise.

5) Tas Drawstring; Tas drawstring dipilih sebagai media pendukung karena kecenderungan remaja yang sebagian besar suka membawa tas saat bepergian, baik itu bersama teman hingga keluarga saat berlibur. Pengguna yang berminat dengan media ini dapat menghubungi nomor yang telah tercantum dalam menu Merchandise. 6) Botol Minum; Botol minum dipilih sebagai media pendukung karena sering dibawa oleh remaja saat bersekolah. Terkadang juga dibawa saat bepergian ke suatu tempat tertentu. Pengguna yang berminat dengan media ini dapat menghubungi nomor yang telah tercantum dalam menu Merchandise. 7) Pouch; Pouch sering digunakan oleh remaja baik untuk membawa alat make up, tempat pensil atau membawa beberapa barang kecil saat bermain atau bepergian. Sehingga cocok bila dijadikan sebagai media pendukung atau merchandise dari media utama. Media ini didapatkan saat event peluncuran pertama dengan syarat dan ketentuan yang berlaku. 8) Notebook; Notebook sering digunakan untuk menulis catatan saat pembelajaran di kelas. Sehingga sosok digunakan sebagai media pendukung. Media ini didapatkan saat event peluncuran pertama dengan syarat dan ketentuan yang berlaku.

9) Mug; Mug merupakan salah satu merchandise dari aplikasi "salim". Media ini didapatkan saat event peluncuran pertama dengan syarat dan ketentuan yang berlaku. 10) Alat Tulis; Alat tulis merupakan salah satu media pendukung yang dimiliki oleh "salim" yang dapat digunakan oleh semua kalangan umur. Media ini didapatkan saat event peluncuran pertama dengan syarat dan ketentuan yang berlaku. 11) Gantungan Kunci; Gantungan kunci digunakan untuk menyebarkan informasi tentang identitas "salim" melalui logo sebagai desain dari gantungan kunci. Media ini dibagikan bersamaan dengan media yang didapatkan saat event peluncuran berlangsung. Dan 12) Graphic Standart manual; GSM dibuat untuk memberikan informasi tentang logo yang digunakan pada aplikasi mulai dari filosofi hingga contoh penerapannya pada media media tertentu.

\subsection{Konsep Verbal}

Penggunaan bahasa Indonesia yang santai dan tidak baku dalam media utama agar lebih mudah dipahami oleh remaja dan tidak terlihat formal. Sehingga remaja lebih mudah dalam memahami informasi yang disampaikan.

\subsection{Konsep Visual}

Agar lebih menarik, dalam multimedia interaktif menggunakan ilustrasi yang digunakan dalam menunjukkan contoh perbuatan baik yang disebutkan dalam materi akhlak. Kemudian beberapa ilustrasi tersebut juga dijadikan sebagai tombol untuk materi akhlak. Karakter dibuat berdasarkan tokoh artis Islam di Indonesia yang dipilih oleh target audiens yaitu Irwansyah dan Zaskia Sungkar. Selain itu, kedua tokoh tersebut juga memiliki prestasi yang banyak sehingga diharapkan remaja dapat terinspirasi oleh prestasi yang dimiliki oleh Irwansyah dan Zaskia. 
Berdasarkan data yang telah dikumpulkan, menunjukkan bahwa perlunya media pembelajaran baru yang menarik dan interaktif. Tidak hanya dapat dipahami secara teoritis tetapi juga secara aplikatif oleh remaja. Serta agar mudah digunakan dan diakses oleh remaja, multimedia interaktif ini menggunakan gadget sebagai outputnya nanti sehingga menghasilkan aplikasi pembelajaran yang berbasis Android. Tidak hanya itu, multimedia interaktif ini juga perlu didesain semenarik mungkin agar remaja tertarik dan nyaman dalam menggunakannya di kehidupan sehari-hari.

Maka perancangan ini menggunakan keyword "Petualang Kebaikan" menciptakan sebuah media pembelajaran yang menarik, tidak hanya menyediakan informasi tentang akhlak terpuji tetapi juga mengajak remaja untuk aktif dalam mengingat kembali dan mempelajarinya. Melalui multimedia interaktif, remaja akan diajak untuk aktif dalam mempraktikkan beberapa perbuatan baik yang disediakan. Sehingga remaja nantinya akan memiliki kebiasaan baru untuk berbuat baik yang terbentuk secara perlahan. Serta dengan penjelasan materi yang mudah dipahami dan menyenangkan, remaja tidak akan mudah bosan.

\subsection{Alternatif Desain}

Peneliti membuat visual sesuai dengan keyword yang telah ditentukan untuk menciptakan desain yang sesuai dengan keyword, target audiens dan beberapa aspek lain. Desain yang telah diciptakan, dikembangkan kembali hingga menemukan beberapa alternatif atau pilihan desain. Alternatif desain akan ditujukan kepada target audiens untuk diseleksi dan dipilih menjadi desain utama.

1) Desain Karakter. Gaya desain yang digunakan mengacu ke acuan visual yaitu flat design yang diterapkan ke acuan karakter desain yaitu Irwansyah dan Zaskia Sungkar yang dipilih berdasarkan hasil kuesioner.

Tabel 1. Perancangan alternatif desain karakter [Sumber: Dokumentasi Penulis]

Acuan Visual Karakter Alternatif Digitalisasi Karakter




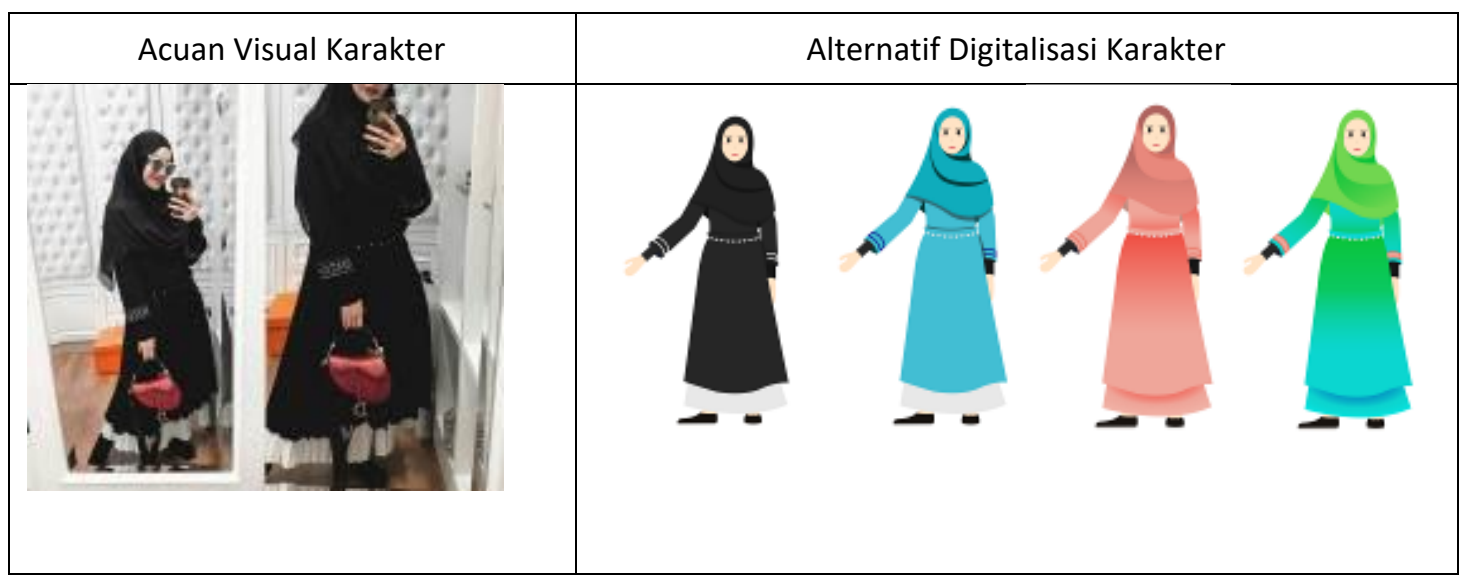

2) Desain Layout. Layout yang digunakan mengacu pada layout aplikasi ruangguru dan referensi dari dribbble.com lalu dikembangkan menyesuaikan acuan warna yang digunakan pada perancangan ini.
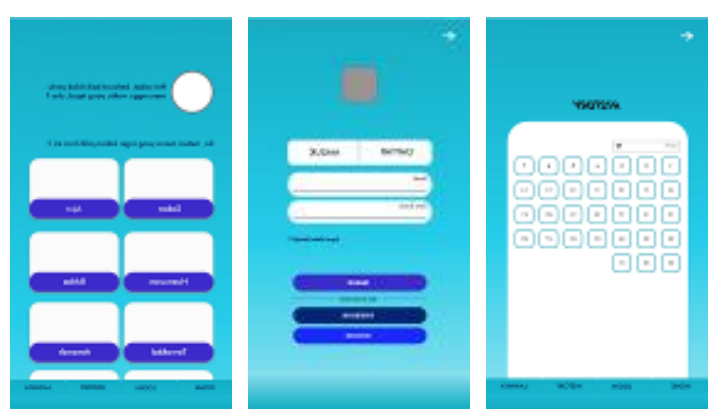

Gambar 7. Alternatif layout pertama

[Sumber : Penulis]

Layout pertama menggunakan background full berwarna dan menggunakan tambahan white space untuk body text. Tombol pada menu Home akan menggunakan ilustrasi yang menggambarkan atau mewakili dari tindakan akhlak terkait.
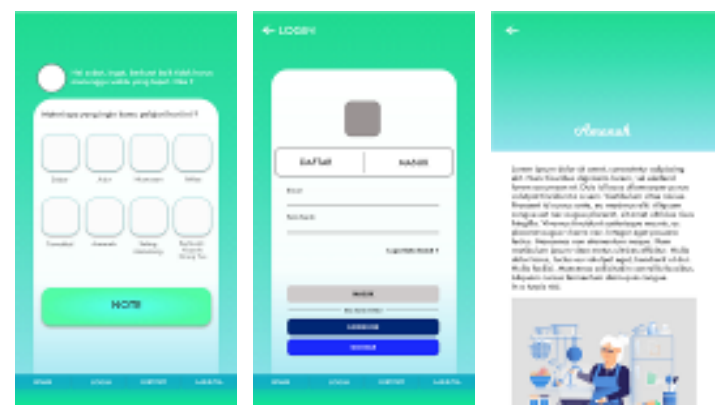

Gambar 8. Alternatif layout kedua

[Sumber : Penulis]

Layout kedua menggunakan background full berwarna dan menggunakan tambahan white space untuk body text sama seperti layout pertama tetapi menggunakan warna 
gradasi hijau. Tombol pada menu Home menggunakan ikon yang mewakili dari tindakan akhlak terkait.

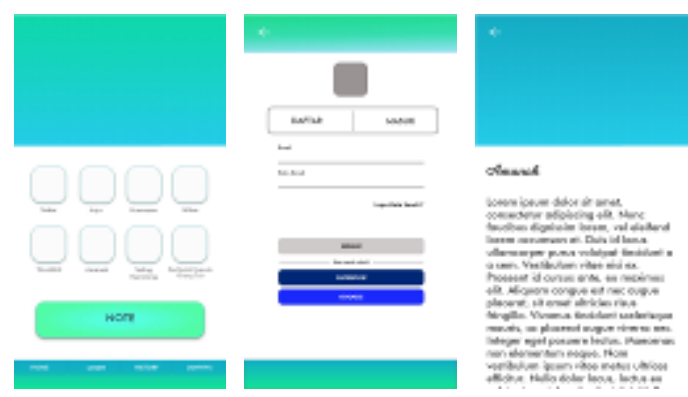

Gambar 9. Alternatif layout ketiga

[Sumber : Penulis]

Layout ketiga menggunakan dominasi white space yang diberi border pada bagian atas dan bawah dengan menggunakan tone warna gradasi hijau. Tombol pada menu Home menggunakan ikon yang mewakili dari tindakan akhlak terkait.

\subsection{Final Project}

Setelah menemukan desain yang menarik dan cocok, desain diterapkan ke semua media yang dibutuhkan dalam perancangan ini. Media pada tahap ini telah siap dioperasikan dan dipublikasikan secara luas terutama ke remaja.
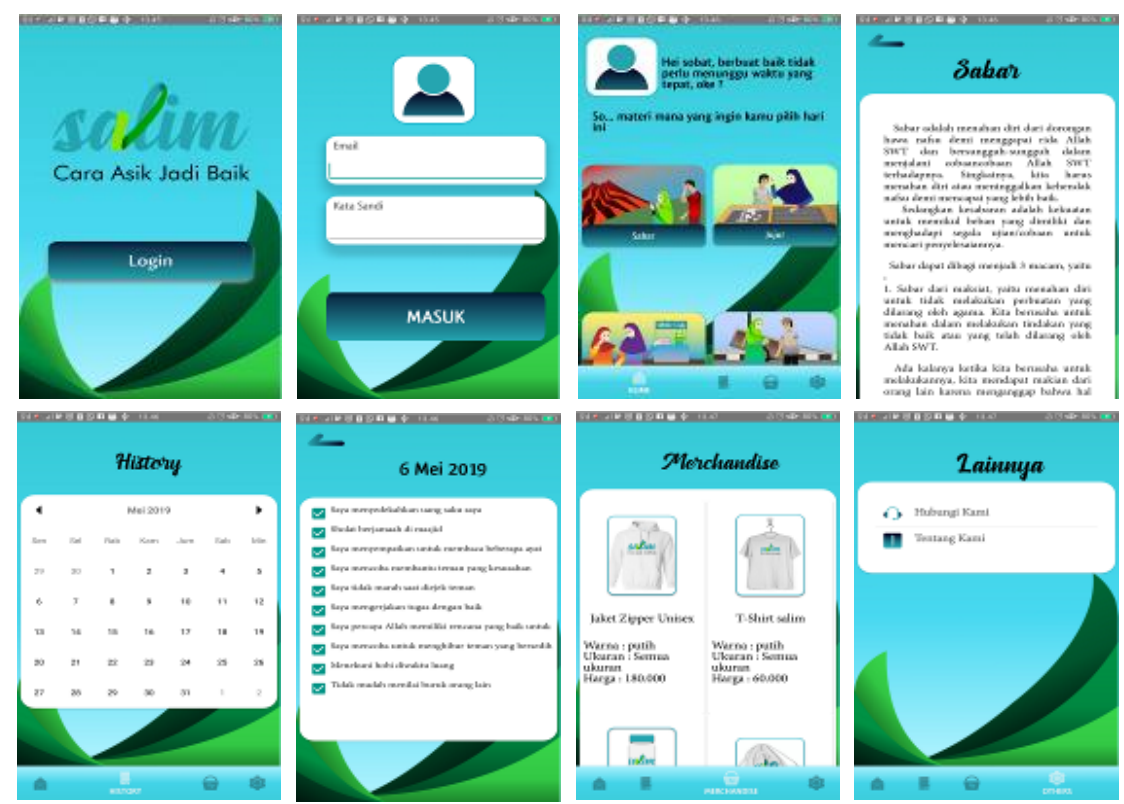

Gambar 10. Desain visual aplikasi SALIM

[Sumber: Penulis] 


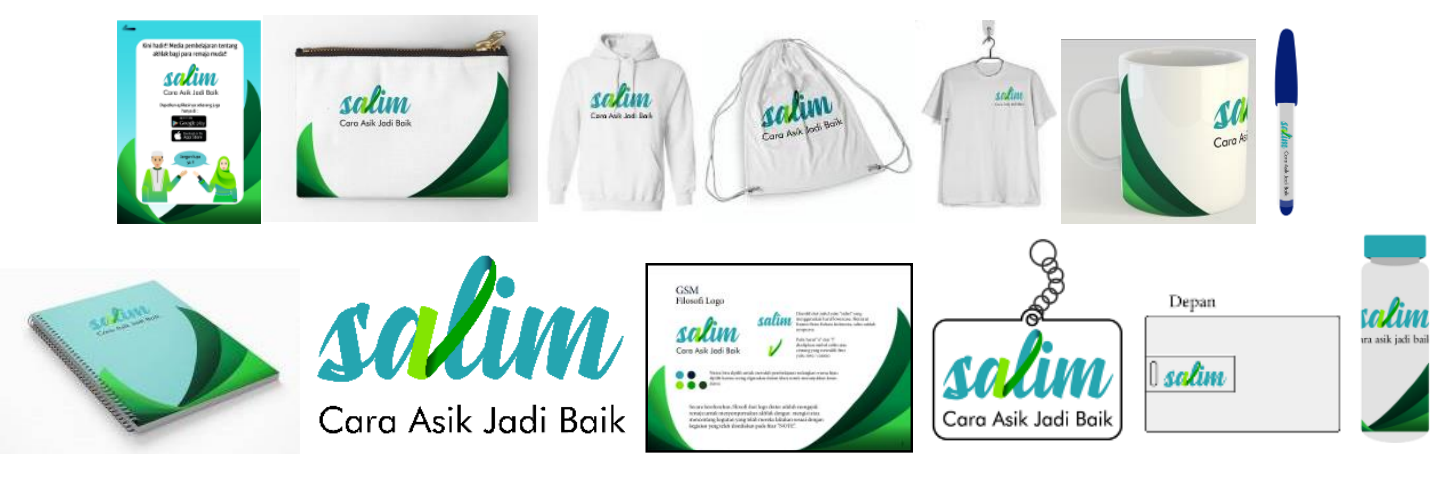

Gambar 10. Desain media sekunder

[Sumber: Penulis]

\section{KESIMPULAN}

Aplikasi android Salim dirancang untuk media bantu bagi remaja dalam mengontrol perilaku sehari-hari. Dengan bantuan aplikasi Salim maka remaja bisa mengontrol apakah hari ini mereka sudah berbuat baik dan bermanfaat bagi orang lain dan lingkungannya atau belum. Jika hari ini mereka belum berbuat baik maka dalam aplikasi poin-poin berbuat baik belum terceklis. Jika hari ini sudah berbuat baik maka poin-poin dalam aplikasi sudah terceklis. Sehingga para remaja bisa mengontrol dirinya sendiri untuk menghindari perbuatan buruk dan melakukan perbuatan baik dalam kehidupan sehari-harinya.

Selanjutnya, bagi penelitian yang akan datang diharapkan ada tema yang membahas tentang sistem pembelajaran melalui media yang dekat dengan siswa, media yang disukai oleh siswa. Contohnya seperti aplikasi android. Media ini sangat dekat dengan siswa, dan merupakan media baru di lingkungan pendidikan. Sehingga dengan media ini maka siswa mendapatkan suasana dan cara baru dalam belajar. Sehingga dalam penelitian tersebut akan memiliki kebaruan.

\section{DAFTAR PUSTAKA}

Abdullah. (2015). Observasi Pengumpulan Data. Romney Dan Steinbart.

Fatmala, D., \& Yelianti, U. (2016). Pengembangan Media Pembelajaran Multimedia Interaktif Berbasis Android Pada Materi Plantae Untuk Siswa Sma Menggunakan Eclipse Galileo Development of Learning Media As Interactif Multimedia Based Android on Plantae Material for Senior High School in Using. Biodik, 2(1), 1-6.

Munir. (2012). Multimedia Konsep \& Aplikasi Dalam Pendidikan. In Antimicrobial agents and chemotherapy.

Qolbiyyah, Shofwatal. (2017). Kenakalan Remaja (Analisis Tentang Faktor Penyebab dan Solusinya dalam Perspektif Pendidikan Agama Islam). Sumbula: Jurnal Studi Keagamaan, Sosial Dan Budaya.

Sugiyono. (2018). Metode Penelitian Kuantitatif, Kualitatif dan R\&D. In ke-26.

Sumara, D. S., Humaedi, S., \& Santoso, M. B. (2017). Kenakalan Remaja dan Penanganannya. Prosiding Penelitian Dan Pengabdian Kepada Masyarakat. 